\title{
The Effect of Organizational Culture and School Climate on the Quality of Education Services and Their Implications on the Quality of the Graduates
}

\author{
Herdianto Wahyu Pratomo \\ Lecturer at Faculty of Islamic Religion-Majalengka University, Indonesia \\ vjherdi@yahoo.com
}

\section{Abstract}

This study was conducted in Islamic Junior High school (MTs) throughout sub-district of Kadipaten, Majalengka, with a focus of research on aspects of organizational culture, school climate, quality of education services, and quality of graduates. This study aims at descriptively analyzing the organizational culture, school climate, quality of education services, and quality of graduate students. Moreover, it also aims at verily analyzing the effect of organizational culture and school climate on the quality of education services in Islamic Junior High school (MTs) throughout sub-district of Kadipaten, Majalengka, both partially and simultaneously, and the effect of the quality of educational services on the quality of graduates. The research method used is descriptive and verification survey methods. Data collection is carried out primarily and secondarily. The sampling method used is proportional sampling using the Slovin formula. The analysis technique used is path analysis. The results of this study indicated that the organizational culture was categorized as good, yet there were still weaknesses in the aspect of the teachers' aggressiveness. The school climate was considered good, yet there were still weaknesses in the aspect of the institutional environment. The quality of education services was quite good, yet there were still weaknesses in the aspect of responsiveness. The quality of graduates was categorized as good, yet there were still weaknesses in the aspects of affective abilities. The results of the verification study showed the organizational culture and school climate had a positive and significant effect on the quality of education services, as well as the quality of education services had a positive and significant effect on the quality of student graduates.

\section{Introduction}

The implementation of education should be arranged systematically. The education can also be done in formal and non-formal education pathways. The formal education pathway can be carried out through schools, both general and other vocational schools. In this case, the school as an institution carrying out educational processes at the micro level occupies an important position because every member of the community can participate in the education process in this institution. These activities aims at preparing the community to gain knowledge and skills to be more able to behave and act in a better community life through the 
schools' pathway. A school is required to be able to implement the school culture with an environment and atmosphere educating students to carry out a comfortable and friendly educational and learning process.

With the atmosphere of a comfortable and friendly school environment, it will cause comfort for students to be able to carry out the learning process. In relation to it, culture is a view of life recognized by a group of people including ways of thinking, acting, behaving and applying the norms of life in the community. Culture can also be seen as a behavior of attitudes values of life and way of life to make adjustments to the environment and way of facing at problems and how to solve them. Nurkolis (Nurkolis, 2003) defined culture as follows:

"Culture is defined as a mental attitude and old habits having been inherent in every step of the activities and work results. Culture is an institutional product rooted from the mental attitude, commitment, dedication and loyalty of each institution's personnel. In School Based Management (SBM), the change of the organizational culture is directed towards achieving the quality of education because the aspects of culture have an important role in achieving the quality of continuing education."

With the organizational culture in schools implemented by members of school organizations (principals, teachers, education staff and students), it is expected that members of the school organization can implement culture well to achieve good school services to create good graduates as well. Schools are required to provide quality services (Clothey, 2013) in which the quality service will create a conducive atmosphere. The responsibility for teaching and learning activities is imposed to the teacher. It is because the teacher interacts directly with the students in the teaching and learning process. An implemented good learning process in every school must refer to the Law of the Republic of Indonesia number 14 of 2005 concerning Teachers and Lecturers, stated in article 4 stating that: "The position of the teacher as a professional serves to improve the dignity and the role of the teacher as an agent of learning functions to improve the quality of national education".

The teacher is the most decisive component in a whole education system. The teachers' ability to organize teaching and learning processes is one of the main requirements for a teacher in seeking better results from the implemented teaching. Teachers will be able to carry out professional tasks well and can act as effective teaching staff if they have fulfilled the competencies that should be owned by a teacher. As stated in the Law of the Republic of Indonesia number 14 of 2005 concerning Teachers and Lecturers in article 4 stating that: "Teachers are required to have academic qualifications, competencies, educator certificates, physically and mentally healthy, and the ability to realize national education goals." Moreover, in Article 10 paragraph 1: "The intended teacher competencies in article 8 include: (a) Pedagogical competence; (b) Personality competence; (c) Professional competence; and (d) social competence." Therefore, in schools, teachers are required to further improve their abilities and professionalism to graduate the intelligent students.

Basically, the school climate is a shared perception of what is happening academically, socially, and environmentally at school regularly. The optimal school climate must be responsive to the needs of each student, stimulate student personal growth, and provide academic services to students properly to produce the quality graduates. Thus, the quality of education refers to the standard process and the quality of results referring to the competency standards of graduates. There is a causal relationship between the quality of the process and 
the quality of the results. If the learning process has a good quality, the competency standard of graduates can be achieved with good quality as well. In this case, the increase of professionalism is a must for the realization of a good education service. Good quality education services tend to produce good quality education graduates. Good quality education is the education quality that can be applied internally or externally.

Criteria of education quality internally can be applied to school institutions by implementing a curriculum that is in accordance with the rules set by the government. Whereas, criteria of the education quality externally are the quality of graduates who can meet the demands of the criteria from educational stakeholders. Achieving the good quality education is not easy. Nowadays, the reality faced by the national education is quite complex, as expressed by (Nanang Fatah, 2000) :

"Education is always deal with problems, including the problem of quality improvement, educational opportunities equalization, the availability of limited budget, and the limited of resources from the community professionally in accordance with the principles of education as a shared responsibility between government, society, and parents."

In this study, the relationship of the four variables between organizational culture, school climate, quality of education services, and quality of graduates refers to the results of the research of (Gantsho and Sukdeo, 2018) studying the organizational culture and the service quality, the research of (Manning et al., 2012) studying the relationship of organizational climate and services, and the research of(Prebble et al., 2014) studying the impact of educational and academic services on the quality of graduates. Based on this empirical review, this study tries to build a paradigm model between organizational culture and school climate on the quality of education services and their impact on the quality of graduates. It is believed to be due to the organizational culture not only producing performance (Salehipour and Ah, 2018) but also having to do with establishing a quality service culture (Khurshid and Awan, 2017), while the organizational climate can provide the organization more effectively (Eshraghi et al., 2011).

Based on a review of the above background, the writer is interested in conducting research on the effect of organizational culture and school climate on the quality of education services and their implications for the quality of the graduates of Islamic Junior High school (MTs) in sub-district of Kadipaten, Majalengka. The writer writes the results of which in the form of scientific work called Thesis entitled: "The Effect of Organizational Culture and School Climate on the Quality of Education Services and Their Implications on the Graduates of Islamic Junior High school (MTs) in Sub-district of Kadipaten, Majalengka."

\section{Research Methods}

This study was conducted to obtain: (1) Description of organizational culture in Islamic Junior High school (MTs) throughout the sub-district of Kadipaten, Majalengka; (2) Description of the school climate in Islamic Junior High school (MTs) throughout sub-district of Kadipaten, Majalengka; (3) Description of the quality of education services in Islamic Junior High school (MTs) throughout sub-district of Kadipaten, Majalengka; (4) Description of the quality of the graduates of Islamic Junior High school (MTs) throughout the subdistrict of Kadipaten, Majalengka; (5) The effect of organizational culture and school climate on the quality of educational services partially and simultaneously; and (6) The effect of the quality of education services on the service quality of students of Islamic Junior High school (MTs) throughout the sub-district of Kadipaten, Majalengka. The type of this research is 
descriptive and verification. It is because this study aims at collecting an overview and information regarding the organizational culture, school climate, quality of education services, and the quality of graduates of Islamic Junior High school (MTs) throughout the sub-district of Kadipaten, Majalengka. Moreover, it also aims at testing the causality among independent variables on the dependent variable through intervening variables, which is the effect of organizational culture and school climate on the quality of education services having implications for the quality of graduates of Islamic Junior High school (MTs) throughout the sub-district of Kadipaten, Majalengka. The research method used was a survey method in which this study took samples from the population using questionnaires and interviews as the main data collection instruments. There are 2 implemented survey methods used. They are the descriptive and explanatory survey. The investigation type is a type of causality aiming at explaining the relationship among variables. In this study, the population was 42 people in which they are all teachers of Islamic Junior High school (MTs) throughout the sub-district of Kadipaten, Majalengka. Based on the Slovin formula, from a population of 42 teachers, a sample of 30 teachers was obtained with a proportional random sampling technique.

\section{Discussions}

The research results are divided into two parts. They are descriptive research and verification research. Descriptive research is assessed based on the results of analysis using calculation of average values, standard deviations. and range of values. Meanwhile, verification research is assessed based on the results of path analysis and hypothesis testing.

Table 1. Descriptive Analysis of Research Variables

\begin{tabular}{|l|c|c|c|}
\hline \multicolumn{1}{|c|}{ Variable } & $\begin{array}{c}\text { Score } \\
\text { Average }\end{array}$ & $\begin{array}{c}\text { St. } \\
\text { Deviation }\end{array}$ & Categorization \\
\hline $\begin{array}{l}\text { Variable of Organizational } \\
\text { Culture }\end{array}$ & 3.49 & 0.671 & Good \\
\hline Variable of School Climate & 3.48 & 0.755 & Good \\
\hline $\begin{array}{l}\text { Variable of Educational Service } \\
\text { Quality }\end{array}$ & 3.37 & 0.671 & Good Enough \\
\hline $\begin{array}{l}\text { Variable of The Quality of The } \\
\text { Graduates }\end{array}$ & 3.48 & 0.720 & Good \\
\hline
\end{tabular}

Source: Processed Research Questionnaire, 2015

Based on Table 1, it can be seen that the dominant variables in this study are organizational culture with an average value of 3.49 and a standard deviation of 0.671 . These results indicate that the organizational culture in Islamic Junior High school (MTs) throughout the sub-district of Kadipaten, Majalengka, is considered good. The organizational culture in Islamic Junior High school (MTs) throughout the sub-district of Kadipaten, Majalengka, has been very open empirically in accepting changes, especially in the aspects of developing creativity and innovation in learning activities. It is seen from the results of research showing the dimensions of creativity and innovation being the highest dimension when compared to other dimensions (orientation towards results, individual orientation, team orientation, aggressiveness and stability). Based on the results of path analysis research, it can be seen in the picture as follows: 


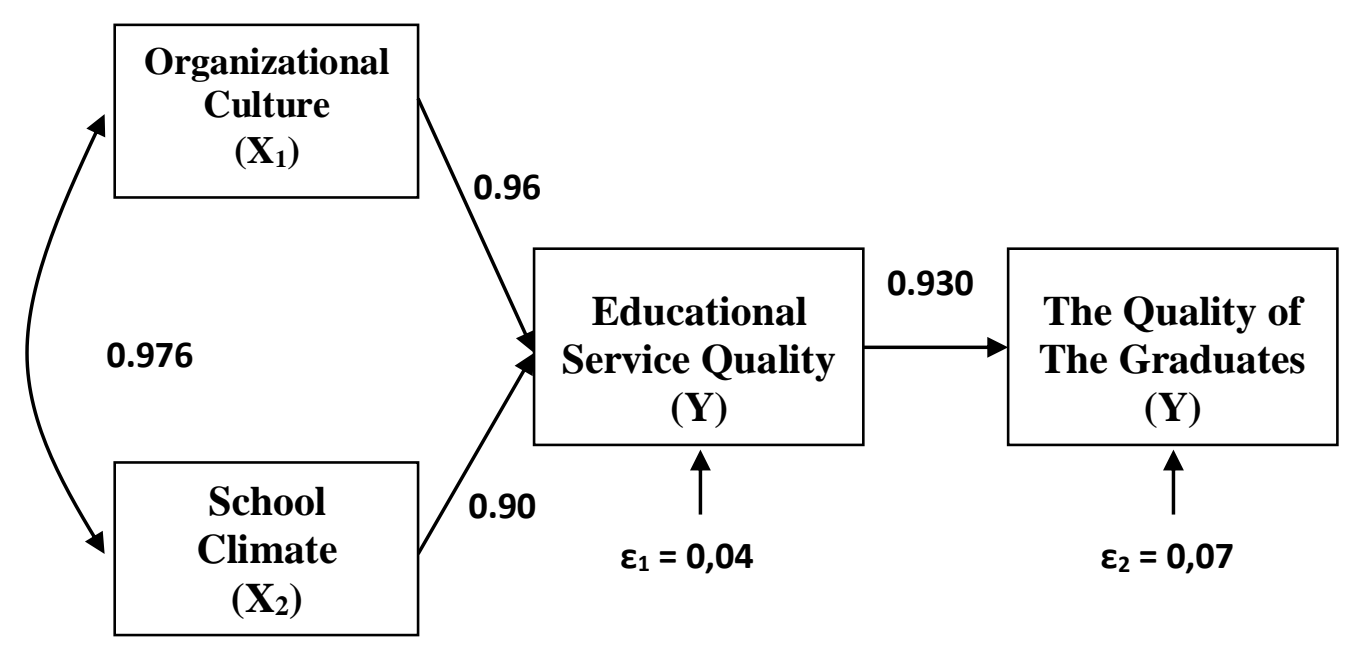

Figure 1. The results of verification research

Organizational culture has a positive and significant effect on the quality of education services. These results give the meaning that the role of organizational culture is an important factor in an organization, especially in improving the quality of educational services. The findings empirically show that the direct effect of organizational culture on the quality of education services has a significant effect. It is based on the existence of a strong relationship between the quality of education services and organizational culture.(Mohammad et al., 2012; Tsoukatos, 2014; Hadian, 2017) in his research proves that organizational culture significantly influences and has an impact on service quality. Likewise, the results of research by (Nascimento, Cecilio and Ribeiro, 2015) stating that organizational culture has an impact on operational performance in the organization.

School climate has a positive and significant effect on the quality of education services. From this result, it means the school climate is the basis for improving the quality of education services. (Manning et al., 2012) It indicates the organizational climate can provide a service climate in increasing user satisfaction. Empirical findings show the school climate will be effective if followed by a good organizational culture. (Schneider, Ehrhart and Macey, 2013) It states that organizational culture and climate are two very important variables in an organization. The results showed the school climate had a greater effect on the quality of education services through organizational culture, while the direct effect of the school climate on the quality of education services tended to be low. The organizational culture and school climate simultaneously have a positive and significant effect on the quality of education services in Islamic Junior High school (MTs) throughout the sub-district of Kadipaten, Majalengka. However, empirically, the two variables simultaneously influence $96 \%$ of the quality of education services and the remaining $4 \%$ is influenced by other factors outside the focus of the study. The quality of education services has a positive and significant effect on the quality of graduates. (Shafig Al-Haddad, 2018) stated in their research that with the improvement of the quality service system, it will have a positive contribution to the quality of graduates who ultimately can provide satisfaction to students. These results give the meaning that the quality of educational services is a stimulant for the achievement of the quality of graduates having been set based on graduate quality standards. The hypothesis testing results in this study were all accepted. it means that the model built in the research paradigm was empirically proven that organizational culture, school climate had a positive 
and significant effect on the quality of education services and the quality of education services had an impact on the quality of graduates.

\section{Conclusions}

The organizational culture in Islamic Junior High school (MTs) throughout the subdistrict of Kadipaten, Majalengka, has optimally supported the quality of education services, yet there is still weakness which is the low aggressiveness of teachers. The school climate in Islamic Junior High school (MTs) throughout the sub-district of Kadipaten, Majalengka, has optimally supported the conduciveness of student learning processes, yet there is still weakness which is the low relationship between schools, parents, and the environment. The quality of education services in Islamic Junior High school (MTs) throughout the sub-district of Kadipaten, Majalengka, has been optimally implemented, yet there is still weakness which is the low responsiveness of teachers toward student needs. Organizational culture and school climate have a positive and significant effect simultaneously (together) on the quality of education services. It means the organizational culture and school climate are factors influencing the quality of education services held in Islamic Junior High school (MTs) throughout the sub-district of Kadipaten, Majalengka. The quality of graduates of Islamic Junior High school (MTs) throughout the sub-district of Kadipaten, Majalengka, has been optimally maintained, yet there is still weakness which is the lack of affective abilities of students. The quality of education services has a positive and significant effect on the quality of graduates. It means the quality of education services is a stimulant for the of the of having been based on standards.

\section{References}

Clothey, R. (2013) 'Perceived Service Quality in Schools of Education: A Comparative Study between Drexel University and Gazi University School of Education School of Education', American International Journal of Social Science, 2(7), pp. 6-15.

Eshraghi, H. et al. (2011) 'The Relationship between Organizational Climate and Leadership Styles of the Managers of Physical Education Offices in Isfahan Province Department of Physical Education and Sport Sciences, Central Tehran Branch, Islamic Azad', Australian Journal of Basic and Applied Science, 5(12), pp. 1985-1990.

Gantsho, Y. and Sukdeo, N. (2018) 'Impact of Organizational Culture on Service Quality', IEOM Society Internationa, pp. 1659-1667.

Hadian, D. (2017) 'The Relationship Organizational Culture and Organizational Commitment on Public Service Quality; Perspective Local Government in Bandung , Indonesia', International Review of Management and Marketing, 7(1), pp. 230-237.

Khurshid, F. and Awan, M. U. (2017) 'Service Quality and Organizational Culture as Predictors of Faculty Job Satisfaction', Pakistan Business Review, (July 2017), pp. 499-517.

Manning, M. et al. (2012) 'Organizational Climate and Service Climate in Tourism and Hospitality: A Review', Journal of New Business Ideas \& Trends, 10(2), pp. 1-18.

Mohammad, A. A. et al. (2012) 'The relationship between organizational learning culture and internal service quality in Iran' s Ministry of Sports and Youth', European Journal of Experimental Biology, 2(4), pp. 1220-1225.

Nanang Fatah (2000) Landasan Manajemen Pendidikan. Bandung: Remaja Rosdakarya. 
Nascimento, L. Do, Cecilio, M. and Ribeiro, L. C. (2015) 'on operational performance International Journal of Operations \& Production Management Article information ':, International Journal of Operations \& Production Management, 35(10), pp. 14601484.

Nurkolis (2003) Manajemen Berbasis Sekolah. Teori Model dan Aplikasi. Jakarta: Raja Grafindo Persada.

Prebble, T. et al. (2014) Impact of Student Support Services and Academic Development Programmes on Student Outcomes in Undergraduate Tertiary Study: A Synthesis of the Research. New Zealand: Massey University College of Education.

Salehipour, A. and Ah, A. (2018) 'The Impact of Organizational Culture and Performance Work System on Employees' Performance', International Business Research, 11(6), pp. 199-212. doi: 10.5539/ibr. v11n6p199.

Schneider, B., Ehrhart, M. G. and Macey, W. H. (2013) 'Organizational Climate and Culture'. doi: 10.1146/annurev-psych-113011-143809.

Shafig Al-Haddad, R. A. T. and S. B. (2018) 'The Impact of the Education Services Quality on Students Satisfaction: An Empirical study at the Business Schools in Jordan The impact of the education services quality on students ' satisfaction : an empirical study at the business schools in Jordan Sha', Journal, International Excellence, Business, 14(3), pp. 393-413. doi: 10.1504/IJBEX.2018.10010423.

Tsoukatos, E. (2014) 'Impact of culture on service quality: What we know and what we need to learn', (January 2011). 